\title{
Information Systems Research and Academic Societies in Japan: an Overview
}

\author{
Osam Sato \\ Faculty of Business Administration \\ Tokyo Keizai University \\ 1-7 Minamichou, Kokubunjishi, Tokyo, 185-8502 Japan. \\ osamsato@tku.ac.jp \\ Takeshi Kosaka \\ School of Management, \\ Tokyo University of Science, \\ 500 Shimokiyoku, Kuki, Saitama, 346-8512 Japan \\ kosaka@ms.kuki.tus.ac.jp \\ Paul Turner \\ School of Computing \& Information Systems, \\ University of Tasmania, \\ Hobart, 7001, Tasmania, Australia \\ paul.turner@utas.edu.au
}

\begin{abstract}
Japanese information systems (IS) research and the activities and foci of Japanese IS academic societies remain relatively unknown outside of Japan. A number of obstacles including structural and linguistic factors inhibit the smooth transfer and exchange of knowledge between Japanese IS researchers and international colleagues. There is also a lack of research exploring these factors and their consequences. This paper seeks to contribute to addressing both these issues. It commences with an empirical comparative analysis of the research foci of IS researchers in Japan and in the USA, and highlights a marked structural difference with Japanese IS researchers engaged in a more diverse range of activities than their USA counterparts. Using interviews these results are discussed with leading Japanese IS researchers and insights generated in relation IS academic societies and the characteristics and factors influencing Japanese IS research and its under-representation in the international IS community.
\end{abstract}

Keywords: IS Research, Japan, Academic Society, national characteristics. 


\section{Introduction}

Information Systems (IS) as an academic field is still young, and has a short history. MIS Quarterly (MISQ), one of the oldest and most prestigious IS journals was only first published in 1977. Truex et.al. (2006) "it is clear that our field is still young and relatively interdisciplinary." Perhaps as a consequence, it is not surprising that the existence of a core body of IS theory is sometimes doubted (King et al., 1997), and certainly the border between IS and the other related fields continues to remain blurred. "IS research has long been characterized as a 'fragmented adhocracy' (Banville et al., 1989) in that it is not dominated by a single methodological or theoretical paradigm but rather by pluralism in both method and theory" (Truex et al., 2006).

While debates over the theoretical core, identity and academic legitimacy of IS have continued (Hirschheim, 2003; Hirschheim, 2006; Weber, 2006; Lyytinen et al., 2006; Avison et al., 2006), some writers have suggested this actually contributes to a "resistance to IS as an academic field based on diversity or lack of coherence" (Davis et al., 2005). There does appear to be a lack of commonly agreed core concepts in IS, such that it has been argued by some that there are "too many fuzzy or ill-defined concepts used in information systems area" (Falkenbarg et al., 1998). Regardless of these perspectives, following Truex et al. (2006) it is relatively clear that "the IS discipline has evolved with relatively permeable research boundaries" and that as an academic field of study IS continues to try to establish its own theories and circumscribe its borders in circumstances where "the relative lack of core theories [is] frequently discussed as a key problem" (Truex et. al., 2006). For the foreseeable future it appears probable that debates about the identity and core body of theory in IS will continue and that their resolution is unlikely to be quick or easy (Grover, V., et. al., 2006; Wade et. al, 2006).

Despite its youth the IS field has generated a large number of international journals including: MISQ, Information Systems Research (ISR), and Information Systems Journal (ISJ). These journals continue to attract large numbers of submissions for publication from a wide cross-section of international researchers. The same is true for a number of IS-specific international conferences including: ICIS, ECIS and PACIS. However, it is very noticeable within these journals and conferences that there is a significant lack of published research from Japanese IS researchers. Given the industrial, economic and educational strength of Japan this lack of published research is surprising. Reciprocally, there have also only been a few publications outlining international IS academic activities and research results that have specifically targeted Japanese IS researchers (Ura et al., 1992; Sato, 1998; Hanaoka, 1998; Nakajima, 2003). Combined these points highlight that there appears to be relatively limited interaction between Japanese and International IS research colleagues. This situation is worthy of more detailed research investigation.

This paper seeks to contribute to this research investigation. Section two introduces three major IS societies in Japan. The paper after section two is divided into two major parts. The first part of the paper identifies some factors that may lead to differences between Japanese and international IS research. These differences are then explored through an empirical comparative analysis of differences in research foci and structure of IS research between Japan and the USA. The second part of the paper explores these differences further through interviews with a number of leading Japanese IS researchers and a survey of academic societies to generate insights into the factors and characteristics of IS research and education in Japan.

\section{Histories and Activities of Academic Societies in Japan}

IS in Japan has tended to be recognized as 
an interdisciplinary discipline. Japanese IS academic societies were established by researchers both from management and engineering. There are three IS academic societies identified in Table 1 . It should be noted that there is also another large academic society "Information Processing Society of Japan (IPSJ) ${ }^{1}$," which is dedicated to computer science, software engineering and IT. The size of membership of special interest group $(\mathrm{SIG})^{2}$ which concerned solely with IS within IPSJ is small. Therefore it is not included in this paper. This section examines each of these three societies in-turn starting with the oldest society.

\begin{tabular}{|l|l|l|l|}
\hline \multicolumn{1}{|l|}{ Table 1. IS societies in Japan } & \multicolumn{1}{|c|}{ Short } & $\begin{array}{l}\text { Established } \\
\text { year (1) }\end{array}$ & $\begin{array}{c}\text { \# of membership } \\
\text { (2) }\end{array}$ \\
\hline Japan Society of Information Management & JSIM & 1979 & 818 (March 2008) \\
\hline $\begin{array}{l}\text { Japan Academic Society of Management } \\
\text { Information }\end{array}$ & JASMIN & 1992 & 1,546 (April 2008) \\
\hline Information Systems Society of Japan & ISSJ & 2005 & 425 (May 2008) \\
\hline
\end{tabular}

Notes: (1) homepage of each organization, (2) Annual reports of each organization

\section{The Japan Society for Information Management}

The Japan Society for Information Management (JSIM) $^{3}$ is the successor of Japan Study Society of Office Automation (JSSOA). JSSOA was founded in 1979 when Office Automation (OA) or business applications of IT had become popular both in business practice and amongst scholars in Japanese Universities. JSSOA studied OA and related business applications of IT from a management perspective. As a result of the active leadership of its past president (Hiroaki Wakuta), its membership had grown to more than 1,000 members by the end of the year 2000, although subsequently its membership has declined slightly. JSSOA had issued an academic journal entitled "Office Automation" quarterly every year. Although JSSOA does not have IS in its name, the research goals of JSSOA were the same as the current IS discipline. In this regard, it is worth noting that at the time of its establishment the word "IS"and even the word "IT" was not in regular usage. Indeed the ICIS conference was not founded before $1980^{4}$. Over time the word "OA" became less commonly used and JSSOA changed its name to JSIM in 2006 under the leadership of the third president, Akira Tohyama of Chuo University. JSIM has a strong management and organizational theory orientation. Tohyama (2007), prior to becoming the president of JSIM, wrote "Traditional organization theory has long been accepted as the conceptual base of information management research and practice of informatization." JSIM continues to publish a journal quarterly; this is the "Journal of Information and Management (JIM)".

\section{The Japan Society for Management Information}

The Japan Society for Management Information (JASMIN) was founded in April 1992, to promote research and discussion on the study of Management Information" ${ }^{5}$. It has been established under the leadership of Takehiko Matsuda of the Tokyo Institute of Technology (TITech). Matsuda was one of the most famous scholars in management sciences (MS) area and served as the 20th president of TITech from 1981 to 1985 . He was also appointed as the president of the International Federation of Operational Research Societies (IFORS) from 1974 to $1976^{6}$. So the core establishment of JASMIN consisted of MS scholars from TITech. It should be noted that the aim of JASMIN is focused on management information but not on management information systems. 
Almost simultaneously the Academy of Management Information (AMI) had been established by IS researchers from management schools in Japan. The first president of AMI was Tadao Miyakawa of Hitotsubashi University. He was at the time one of the most famous management scholars in Japan. Both presidents of JASMIN and AMI wanted to make each organization interdisciplinary and aggregate the academic research power of IS researchers in Japan. So they merged the two organizations, JASMIN and AMI, in 1992 and continued to use the name of JASMIN as English name. The merger renewed JASMIN and made it a larger and more interdisciplinary society. Following Takehiko Matsuda, Tadao Miyakawa was appointed to become the second president of JASMIN. JASMIN also produces a quarterly academic journal. JSIM and JASMIN both also hold national meetings twice a year respectively. Although these organizations are independent, more recently both have been engaged in friendly discussions and activities including co-hosting a national meeting in 2006 and international meeting (APCIM $2009^{7}$ ) in 2009.

\section{The Information Systems Society of Japan}

The Information Systems Society of Japan (ISSJ) was founded in $2005^{8}$ as a society of IS researchers. It is a young and small organization with a strong practitioner focus amongst its members. ISSJ also tends to focus more on engineering and less on management, but it aims to be interdisciplinary and to address IS rather than CS (computer sciences) in its research themes and approach. The focus is not MIS but IS. It has a less business and/or management point of view than JASMIN or JSIM. Its focus is more on the information systems themselves and their direct social impact. ISSJ publishes a web journal. However, the papers published remain few because of the small size of its membership, the smaller share of academic people involved, and the disagreements over the appropriate definition of core of IS. Core people in ISSJ do however understand the importance of IS education. President Houjyo (2006) counts IS education, interaction between practitioners and academics, and pursuit of future IS as the three main themes of ISSJ.

\section{Duplication of Memberships}

Across these three societies it is noticeable that many IS researchers are members of all or some of them as well as many other related and special interest societies, whose foci are information security management, information processing, telecommunication, management system, telework, or others societies. These societies are also active. Every society has either one or two national conferences a year, usually spring and fall. All societies publish a journal of the society either as a published paper or web journal.

In returning to the key focus of this paper it is clear that there is a relationship between the domestic societies described above and the lack of representation of Japanese IS research outside of Japan. This relationship is partly because these societies hold most of their meetings only in Japanese and publish their journals only in Japanese. As a result the activities of most Japanese IS researchers remain firmly internally focused on the Japanese research community. The time and cost of international travel is also a barrier when there are national conferences to attend. One reason that Japanese IS researchers don't attend international meetings or conferences is that there is enough of an academic market within the country, i.e. so many schools that need IS instructors in Japan, these candidates don't need to go abroad to give their presentations, and to accumulate research products (published articles and presentations). Many Japanese IS researchers have little incentive to attend international meetings or conferences. 


\section{Exploring differences in} Japanese \& International IS research

Japanese IS research and the activities and foci of Japanese IS academic societies remain relatively unknown outside of Japan. It seems evident that one major obstacle is the language barrier, but this cannot provide a complete explanation for the continued lack of published Japanese IS research internationally. This is particularly the case given that this problem has been recognized in Japan for a number of years. Indeed, as early as 1993 a number of researchers voluntarily held a panel discussion at the ICIS conference to discuss this situation (Watson et al., 1993). These types of meetings have continued including perhaps most recently the invitation to a number of Japanese researchers to participate in the 2007 DSI annual meeting to explore this continuing situation (Matsui et al., 2007). In some senses, this lack of interaction and mutual understanding of Japanese IS research has led to the danger of it becoming idiosyncratic and disconnected from the rest of the world a kind of Galapagos Islands of the IS research community!

A number of distinctive aspects of Japanese IS research and the activities and foci of Japanese IS academic societies that appear evident are the broader focus and diversity in research topics and range of contributors as well as the administrative placement of IS academics within Japanese universities. Based on the experiences and perceptions of the authors the diversity and breadth of IS research is wider in Japan than elsewhere. As a result, membership of Japanese IS societies also appears to be much more diverse than those of comparable international counterparts. IS departments in Japanese universities also appear to contain fewer dedicated IS academics with many staff being drawn from a diverse range of other disciplines. Not surprisingly this has impacts on the coherence of staff research within these IS departments. As Gable et.al. (2007a) notes "Most commonly in the past in Australia and Korea and even more so in America, information systems groups have [tended to be] located within a business faculty. Within Australia there are now many instances of information systems groups located outside the business faculty."

Most of the factors identified above were primarily based on the experiences and perceptions of the authors and had not been grounded in an empirical study per se. However, following an extensive literature search no research papers describing or analysing the nature and type of Japanese IS research or differences with IS research elsewhere could be found. As a result it was decided to conduct an empirical comparative analysis of the different nature and research foci of IS researchers in Japan and in the USA to contribute to addressing these issues.

As part of background preparation for the comparative analysis it was important to clarify understanding of the underlying definition of IS in a Japanese context. This was to determine whether the relative absence of papers by Japanese researchers in international journals or conferences was in part due to lower submission rates or different classificatory approaches to defining IS being used in Japan. In this regard, the publication entry sheets for submissions to the journal of JASMIN (the largest of 3 IS-related academic societies in Japan) were examined. Table 2 shows a list of the theme categories identified in 2007 from which an author has to select one to submit their manuscript. As Table 2 illustrates, 'Information Systems' is just one of many possible entry selections. The other entries are not necessarily linked directly to IS. 


\section{Table 2. Theme Categories for Manuscript Submission}

Strategy

Organization Theory

Decision Making

Systems Science

Knowledge System

Information Systems

Knowledge Management

Business Process

Marketing

e-business

Innovation \& New Product Development

Production and Operation Management

Business Relationship \& Logistics

Operations Research

Others

\section{Table 3. Tracks of Three Conferences}

\begin{tabular}{|c|c|c|}
\hline ICIS 2008 & AMCIS 2008 & JASMIN 2007 \\
\hline $\begin{array}{l}\text { Ethics, Design, and Consequences } \\
\text { Education and Development } \\
\text { Design Theory and Research } \\
\text { Featured Industries } \\
\text { Research Methods } \\
\text { Organization Theory, Strategy and } \\
\text { IS } \\
\text { Human Behavior and IT } \\
\text { Human Computer Interaction } \\
\text { Alternative Systems Development } \\
\text { Teaching Cases } \\
\text { Social Aspects of IS } \\
\text { Global Information Systems } \\
\text { Management } \\
\text { Extreme InNovation } \\
\text { IS Security and Privacy } \\
\text { General Topics Track } \\
\text { Breakthrough Ideas } \\
\text { EcoNomics of Information Systems } \\
\text { ClO Problems and Prospects }\end{array}$ & $\begin{array}{l}\text { International and Cross Cultural } \\
\text { Issues IT Diffusion } \\
\text { Decision Support, KNowledge and } \\
\text { Data Management Systems IT in } \\
\text { Health Care } \\
\text { E-business and E-commerce } \\
\text { Information Systems Education } \\
\text { Research } \\
\text { End-user Information Systems and } \\
\text { KNowledge Management } \\
\text { Information TechNology and its } \\
\text { Impact in Latin America } \\
\text { Enterprise Systems Security, } \\
\text { Assurance and Privacy } \\
\text { Human Computer Interaction } \\
\text { Studies in Information Systems } \\
\text { Analysis and Design } \\
\text { General Topics }\end{array}$ & $\begin{array}{l}\text { +Medical Management and IT } \\
+ \text { CIO } \\
+ \text { +IT investment and } \\
\text { performance } \\
+ \text { +e-learning } \\
\text { Manufacturing and logistics } \\
\text { Network frontier } \\
\text { +IS development } \\
\text { Marketing \& e-Business } \\
\text { +ERP } \\
\text { Education and case teaching } \\
\text { SCM } \\
\text { Ubiquitous society } \\
\text { Life Information } \\
\text { Government Policy } \\
\text { +IT investment \& portfolio } \\
+ \text { KNowledge Management } \\
\text { Human Resource } \\
\text { Development } \\
\text { Business Strategy } \\
+ \text { Conceptual Models } \\
\text { KNowledge Property } \\
\text { Public Service } \\
+ \text { IT Investment } \\
\text { Agency and PolyAgency } \\
\text { Data and Text Mining } \\
\text { Business Game }\end{array}$ \\
\hline http://www.icis2008.org/ & $\begin{array}{l}\text { http://www.business.mcmaster.ca/a } \\
\text { mcis2008/mini-tracks.htm }\end{array}$ & $\begin{array}{l}\text { Proceedings of the National } \\
\text { Conference, Spring } 2007 .\end{array}$ \\
\hline
\end{tabular}


The tracks of conferences were also examined and briefly compared with two international conferences. Table 3 illustrates a list of tracks in the 2007 spring conference held by JASMIN along with those of ICIS 2008 and AMCIS 2008. Most of tracks in ICIS and AMCIS are concerned directly with IS related areas. These contrasts markedly with tracks in the JASMIN conference where only those marked with + sign can be classified as IS or IS related areas. As Table 3 illustrates, only 10 out of 25 , about half of the JASMIN conference tracks are indirectly linked to IS related areas.

These background points assisted in clarifying understanding of the underlying definition of IS in a Japanese context which appears to view IS as part of a much broader and diverse range of research activities. This in-turn suggests that membership of Japanese IS societies is more diverse than those of comparable international counterparts.

\section{Research Method and Data}

\section{Research Method}

In conducting an empirical comparative analysis of the nature and research foci of IS researchers in Japan and in the USA this paper focused on an analysis of the distribution and diversity of academic affiliations of these IS researchers. This quantitative analysis involved counting affiliations of IS researchers both in AIS and Japanese academic societies, and comparing their distributions of affiliations. The three data sets utilized for this analysis were:

- The 1995 Directory of Management Information Systems Faculty edited by MISRC/McGraw-Hill. This directory lists universities in USA and Canada alphabetically by state. IS (and MIS) faculty members are listed in each university respectively and are alphabetically sorted by surname.

- The directory of JASMIN members published in 2000 . o The directory of JSIM members published in 2004.

As a control sample schools and colleges of AIS members from the "1995 Directory of Management Information Systems Faculty" were counted. This involved listing the type of school or college, and counting the number of faculty members belonging to AIS. The following rules were used to derive names:

- If the name of either school or college is available, use it to group/categorise the school. For example, "School of business" or "College of business" is counted as "business".

- If the name of department is available, use it to group/categorise the department. For example, "Department of management" is counted as "management."

- Where names were unavailable data was not used and handled as a missing value.

\section{Research Data and Results}

This comparative analysis was based on Japanese and USA data. Canada and Guam data were excluded. Information such as "Center of ..." in the directory was ignored and not counted as a member of the data set. Graduate and undergraduate schools were both counted. By using generic naming/categorizing rules it became possible to compare the distribution of names, i.e., affiliations, between AIS and Japanese IS societies (JASMIN and JSIM) members. In total 433 schools in USA were categorized and 2,229 IS (MIS) faculty members counted. Some schools have same name, and same name are summarized. The process results number of school name to 116 , which is employed as our control sample to compare against Japanese. Table 4 lists the 20 most frequent school names after the weighting. The weighting was generated by multiplying each generic school name by the number of IS faculty members in each school name.

Further integration and categorization of school names was made to aid comparison 
using the following rules:

- 'Accounting' and 'accountancy and information systems' were integrated into accounting.

- 'Business,' 'business administration,' 'business and administration,' 'business and administrative science,' 'management,' and 'management and business' were integrated into business.

- 'Computer and information systems,' 'computer information systems,' and 'computer information management' were integrated into computer information systems.

- 'Computer sciences and information systems,' 'computer sciences and mathematics,' and 'computer sciences' were integrated into computer sciences.

- 'MIS,' and 'MIS and decision sciences' were integrated into MIS.

\begin{tabular}{|c|c|}
\hline School Names & Weighted Sum \\
\hline Business & 589 \\
\hline Business Administration & 475 \\
\hline Management & 209 \\
\hline Computer Information Systems & 103 \\
\hline Business and EcoNomics & 65 \\
\hline Business and Public Administration & 59 \\
\hline Computer and Information Sciences & 37 \\
\hline Accounting & 32 \\
\hline Information and Decision Sciences & 32 \\
\hline MIS & 27 \\
\hline Information Systems & 25 \\
\hline Statistics and Computer Information Systems & 17 \\
\hline Systems Management & 17 \\
\hline Management Sciences and Information Systems & 15 \\
\hline Management Science and Information Systems & 14 \\
\hline Applied Computer Sciences & 14 \\
\hline Computer TechNology & 14 \\
\hline Business and Administration & 13 \\
\hline information Studies & 13 \\
\hline Arts \& Sciences & 12 \\
\hline
\end{tabular}

Above summation process was applied to AIS data in Table 4. And the same analysis and summation rule was also applied to the directory of membership of JASMIN and directory of membership of JSIM. They are compared in Table 5. It is noted that there is a difference of in the publication dates of the respective directories but it was assumed that the names of schools change relatively infrequently and therefore would not invalidate the comparison. The total numbers of JASMIN and JSIM members were 792 and 409 respectively. In compiling these totals, practitioners were excluded as well as members whose affiliations, (name of school or department) were not identified or available, which reduces samples to 631 and 351 respectively (Table 5 ).

From a comparison of Table 5, it is apparent that the percentage of business schools in AIS is much larger than that of JASMIN and JSIM. Although schools of business are the most popular affiliations in all societies, the percentiles are different. The school of business dominates $58 \%$ of AIS, but 
comprises only $28 \%$ and $20 \%$ for JSIM and JASMIN respectively. Also while the "Business and Economics" in AIS is only $3 \%$, "Economics" is $13 \%$ and $18 \%$ in JASMIN and JSIM respectively. The authors note that part of the explanation for this may be that the difference between economics and business is not well distinguished in Japan due to historical reasons.
A further comparison of the most significant names of schools in Table 5 reveals a number of characteristic differences of memberships amongst the three data sets. In terms of the distribution of school names the AIS data is more similar to JSIM data than to JASMIN data. Table 6 shows a more condensed comparison of Tables 5 .

\begin{tabular}{|c|c|c|c|c|c|c|c|c|}
\hline \multicolumn{3}{|c|}{ AIS } & \multicolumn{3}{|c|}{ JASMIN } & \multicolumn{3}{|c|}{ JSIM } \\
\hline $\begin{array}{l}\text { School } \\
\text { Names }\end{array}$ & $\begin{array}{l}\text { Weighted } \\
\text { Sum }\end{array}$ & $\%$ & $\begin{array}{l}\text { School } \\
\text { Names }\end{array}$ & $\begin{array}{l}\text { Weighted } \\
\text { Sum }\end{array}$ & $\%$ & $\begin{array}{l}\text { School } \\
\text { Names }\end{array}$ & $\begin{array}{l}\text { Weighted } \\
\text { Sum }\end{array}$ & $\%$ \\
\hline Business & 1294 & 58 & Business & 155 & 20 & Business & 114 & 28 \\
\hline $\begin{array}{l}\text { Computer } \\
\text { Information } \\
\text { Systems }\end{array}$ & 172 & 8 & Economics & 103 & 13 & Economics & 72 & 18 \\
\hline $\begin{array}{c}\text { Business and } \\
\text { Economics }\end{array}$ & 65 & 3 & MIS & 88 & 11 & Commerce & 50 & 12 \\
\hline $\begin{array}{l}\text { Business and } \\
\text { Public } \\
\text { Administration }\end{array}$ & 59 & 3 & Commerce & 60 & 8 & $\begin{array}{l}\text { Business } \\
\text { Information }\end{array}$ & 30 & 7 \\
\hline Accounting & 43 & 2 & Engineering & 52 & 7 & Engineering & 18 & 4 \\
\hline MIS & 42 & 2 & $\begin{array}{c}\text { Science } \\
\text { and } \\
\text { Technology }\end{array}$ & 35 & 4 & Informatics & 12 & 3 \\
\hline $\begin{array}{l}\text { Information } \\
\text { and Decision } \\
\text { Sciences }\end{array}$ & 32 & 1 & $\begin{array}{l}\text { Business } \\
\text { and } \\
\text { Economics }\end{array}$ & 18 & 2 & $\begin{array}{l}\text { Commerce } \\
\text { and } \\
\text { Economics }\end{array}$ & 7 & 2 \\
\hline $\begin{array}{l}\text { Information } \\
\text { Systems }\end{array}$ & 25 & 1 & $\begin{array}{l}\text { Decision } \\
\text { Science } \\
\text { and } \\
\text { Technology }\end{array}$ & 18 & 2 & Sociology & 5 & 1 \\
\hline $\begin{array}{l}\text { Statistics and } \\
\text { Computer } \\
\text { Information } \\
\text { Systems }\end{array}$ & 17 & 1 & Information & 18 & 2 & $\begin{array}{c}\text { Environmental } \\
\text { Humanity }\end{array}$ & 5 & 1 \\
\hline $\begin{array}{c}\text { Systems } \\
\text { Management }\end{array}$ & 17 & 1 & $\begin{array}{l}\text { Information } \\
\text { Systems }\end{array}$ & 15 & 2 & $\begin{array}{c}\text { Information } \\
\text { Sciences }\end{array}$ & 5 & 1 \\
\hline Others & 148 & 20 & Others & 69 & 29 & Others & 33 & 23 \\
\hline Total & 1914 & 100 & Total & 631 & 100 & Total & 351 & 100 \\
\hline
\end{tabular}

Table 6. Characteristic differences of key memberships in the three societies

\begin{tabular}{|c|c|c|c|}
\hline Names Included & AIS & JASMIN & JSIM \\
\hline Business, Economics, and Commerce & $61 \%$ & $42 \%$ & $59 \%$ \\
\hline Computer and Information & $18 \%$ & $7 \%$ & $14 \%$ \\
Other & $21 \%$ & $51 \%$ & $27 \%$ \\
\hline
\end{tabular}


Results of statistical tests on the significance of differences in Table 6 are as follow:

- The population proportion of schools of business, economics and commerce between AIS and JASMIN, between JASMIN and JSIM are different at $5 \%$ level of significance, but not between AIS and JSIM.

- The population proportion of schools of computers and information among three societies are different at $5 \%$ level of significance.

These results do not however prove JSIM is similar to AIS than JASMIN in terms of research subjects and members' orientations. Based on the authors' observations, JSIM includes more business as opposed to IS academics. Indeed, some members of JSIM do not agree that JSIM is academic society of IS and consider it as more of an academic society for business related research. This perspective is endorsed to some extent by the significant difference in "Computer and Information" in Table 6.

\section{Exploratory Interviews for Discussion}

The second part of the paper explores the differences identified above through interviews with a number of leading Japanese IS researchers and a survey of academic societies to generate insights into the factors and characteristics of IS research and education in Japan.

\begin{tabular}{|l|l|l|l|}
\hline \multicolumn{2}{|l|}{ Table 7. Japanese IS Researchers Interviewed } & Establishment & Location \\
\hline & Department or school & national & Tokyo \\
\hline 1 & Department of Industrial Engineering and Management & private & Tokyo \\
\hline 2 & School of Management & private & Tokyo \\
\hline 3 & School of Business & private & Kanagawa \\
\hline 4 & School of Informatics & prefectural & Osaka \\
\hline 5 & School of Commerce & private & Tokyo \\
\hline 6 & Faculty of Commerce & private & Hokkaido \\
\cline { 2 - 4 } & School of Management & private & Osaka \\
\hline 8 & Faculty of Informatics & national & Kanagawa \\
\hline 9 & School of Management & &
\end{tabular}

\section{Interview Process}

The previous sections revealed structural differences between IS academia in Japan and USA and provide a strong base for a follow-up qualitative investigation with leading Japanese IS academics. Based on the information and opinions from these interviews this paper presents detailed insights into the multi-faceted nature of IS academia in Japan and attempts to provide some interpretation of the factors at play and future directions for research.

Interviews were conducted with leading Japanese IS academics in the period 2006 to 2008 as listed in Table 7. These academics all belong to different universities. The interviews were semi-structured using openended questions about IS research and education in their university. The semistructured question frame used was a Japanese translation of IS-in-PA study (Gable et al., 2007b). Interviewees were also asked about their understanding of the nature of IS research in Japan. All interviews were faceto-face, and took from one to two hours. The interviews were tape-recorded with permission of interviewee and a summary of their answers delivered back to the interviewee for correction and/or the acquisition of additional information. 
The remainder of this paper is organized on the basis of responses generated from the semi-structured interviews. This section covers Incentive systems, and Domestic perceptions of the IS discipline. "IS research in Japan" section and "IS education in Japanese universities" section follow.

\section{Incentive Systems}

Incentive systems are critical drivers for human activity and conduct. This section discusses the nature and relationship between incentive systems and IS researchers in Japan. From the interviews data emerged to suggest that the lack of Japanese IS research presented internationally in journals and conferences is perhaps. At least in part, due to subtle institutional factors faced by Japanese researchers including that there is little institutional pressure for researchers to travel abroad or to expose their research results to international examination. As one interviewee stated "The absence of Japanese IS researchers at the international scene comes partly from that they don't have incentives to go abroad. We have a large domestic market for faculty. There are 744 (MEXT, 2008) universities in Japan. The demand and supply of faculty are self-contained within this country. Why should we go abroad?"

The language barrier was also identified as a major reason why IS researchers do not present their research abroad. However, it also works as an effective entry barrier against foreign IS researchers who want jobs in Japanese universities.

Another reason comes from another incentive system, that of the personnel system in Japanese universities.Researchers after post-graduate degree usually get tenuretracks at an early age and as a result there is limited academic competition among tenured researchers. It is also evident that once tenured, research motivation amongst many IS researchers decreases. Following Gable et al., (2007a) "The famous academic catch-cry of "publish or perish" is never more alive than today in universities" but from the interviewees this is clearly not the case in Japanese universities after the acquisition of a tenure-track.

Economic incentives (i.e. salary and research funds) are also weighted strongly in favour of educational teaching rather than research. One interviewee lamented that "As a typical university in Japan, we have no incentive to do research in my university." Research emerges as something that is less appreciated than good educational teaching in many Japanese universities. Another interviewee said "We have some research funds, of course, but the educational fund is much larger." Indeed the interviews strongly indicate that a large part of the intellectual effort of most Japanese IS academics is devoted to administration, educational teaching, and business, but not towards research. This situation also appears unlikely to change in the short term due to the language barrier and because the academic market is to some extent protected both from foreign and domestic competition.

\section{Perception of IS Discipline}

This section examines the insights generated from the interviews on internal and external evaluations of the IS discipline and more particularly perspectives on whether the IS field is perceived as an independent discipline in Japan. IS has grown modestly as a reference discipline (Wade, et. al 2006) such that its contribution to other related academic fields is not always well known. Foreign academic researchers, especially those from US business schools acknowledge IS as an academic field within the management or business discipline (Nakajima, 2003; Wade et al. 2006; Davis et. al., 2005). This seems to be an international standard, however this segmentation of IS is understood differently by many Japanese IS researchers. Some Japanese IS researchers do not recognize IS as a management or business discipline. Further more, while Davis 
et al. (2005) distinguishes IS from other related disciplines, (e.g. informatics) this difference appears to be somewhat ambiguous to many Japanese IS researchers.

The IS discipline has a history that it has been recognized and grown as a typical interdisciplinary field from many related research domains, especially from organization sciences (OS), computer sciences (CS), and management sciences (MS) (Culnan et al., 1986; Grover et al, 2006). In Japan however it is management, CS, MS, OS, engineering, sociology, and psychology, that have been the main contributors to the development the IS discipline. Because of this large number of influences and base disciplines, IS is not limited to the sub-field of management in Japan. Indeed, although IS is often viewed as a field within the management discipline in some other countries (Wade et al., 2006; Gable et. al., 2007a), many IS researchers in Japan do not appear to agree with this point of view. One interviewee confessed to us "I am surprised to find that about $90 \%$ of participants at ICIS come from management schools." International IS conferences are delegated by many faculty members from management schools. In Japan, however, IS is viewed as a more interdisciplinary field, such that more diverse researchers are active in IS-related societies.

While IS or management information systems (MIS) have often been established as a department or a course within management schools in Japan, it is noticeable that the academic contribution to IS from these schools or department is limited. In fact a more diverse range of schools and scholars including engineering, sociology and economics appear to have contributed more directly to these types of IS departments. Therefore, IS in Japan has tended to be much more affected by other related academic disciplines than by management. In Japan, management research from the perspectives of engineering is more active (Nakajima, 2005). IS is recognized and has grown as a management discipline in other countries, USA in particular (Gable et. al, 2007a), while Japanese IS has traced a different path. Indeed, many of the interviewees raised questions such as: "Why has IS not been established as a branch of computer sciences or sociology? Why does IS have to be appreciated, not as an engineering discipline, but as a management discipline in other countries?"

The lack of "theoretical core/identity and academic legitimacy in IS" discussed above has also impacted on the presence of Japanese IS researchers at national and international conferences. As one interviewee commented, "Both Japanese government and industry don't recognize IS as an independent discipline". "Even when IS related accidents erupt and appear in the newspaper, those who are interviewed are not IS researchers but management and computer science people. This symbolizes the lack of presence or recognition of IS societies in Japan." It also highlights the limited presence of IS as an independent field within Japanese academic, business and government spheres.

There are also some debates on the core body of theory in IS and on its definition in Japan. It is noticeable that these debates appear more radical than in other parts of the world. Obata (2006) makes the following criticism "With a close investigation of MISQ and ISR issued in 2001 to 2002, we found that a third of their articles missed IT results and factors that constitute nomological net of IS directly. They include wide variety of articles about online consumer behavior, creation of reliability, research methods, online service, collaboration, decision making, knowledge management, resource allocation, online community, SCM, and etc." $\mathrm{He}$ continues "Unless IS research has any difference from already established academic domains (marketing, operations management, organization behavior etc.), why do we have to continue investment of more intellectual efforts to this domain?" Some Japanese IS 
researchers also suggest that there is a diminishing boundary between IS discipline and others published in international journals. This suggests that Japanese IS researchers tend to lose their motivation for questioning the diversity of participants in IS-related societies. It also might be concluded that neither academics who participate in ISrelated societies nor external agencies including industry, government and the mass media consider IS to be an independent academic discipline.

\section{IS Research in Japan}

The fact that there remains no common understanding of IS amongst researchers in Japan has often resulted in the usage of a blurred and rather ambiguous general definition. It has also led to many IS researchers in Japan viewing the IS domain as covering a much broader area than is accepted outside of Japan. The variety of sub-areas of IS, (i.e. 'fragmented adhocracy') may inhibit IS researchers from discussing in detail IS and its boundaries leaving individual researchers to define IS from within their own specific domain and without any attempt to acknowledge alternate definitions. This inturn has tended to contribute to an expansion in the boundary of IS without leading to greater clarity on its definition. Aligned to this is the consequence that IS in Japan continues to deviate from what are becoming more accepted boundaries of IS internationally. As one interviewee said "Research themes and contents seems to be somehow different between ICIS and JASMIN." The obscurity of the boundaries of IS in Japan may be bad news, but may also have some potential because by having a wider research area, it may actually open up new opportunities for inter-disciplinary research and application development.

\begin{tabular}{|l|}
\hline Table 8 Perceived Characteristics of IS Research in Japan \\
\hline Narrowness of area covered by research \\
\hline Small contribution to IS service industry \\
\hline Little relationship to related academic domains. \\
Shortage of research for education \\
\hline Not practical, too conceptual \\
\hline Slant on information engineering \\
Fragmented subjects \\
\hline Little link to international research \\
Short to international expectation \\
\hline Little interaction to industry \\
No contribution to the actual society \\
\hline Absence of interpretative research \\
\hline
\end{tabular}

Table 8 lists perceived key characteristics of IS research in Japan identified through the interviews. From these findings an image of IS in Japan emerges of an internationally isolated but wide research field, with some connections to industry and Japanese domestic society and only a few international links. It is worth noting that the Table 8 shows that there are Japanese IS researchers who consider the area covered by Japanese academic societies is still too narrow. These opinions reflect the diversity of participants in the academic societies mentioned in part one of this paper. This breadth of coverage in Japan may mean that sometimes depth is sacrificed, such that some researchers may feel a shortage of depth in their subfield of her interest. 
Table 8 also lists another problem, that is, IS research in Japan often tends to be too conceptual to form strong links with industry, government and society. The tendency for universities in Japan to retain an 'ivory tower' approach that does not reward applied research appears to continue. Interviewees report that research focus into fundamentals has continued to receive a much greater appreciation than research into their application. IS has not succeeded in creating an effective relationship between research and industry in Japan.

\section{IS education in Japanese Universities}

This paper is primarily concerned with the lack of representation of Japanese IS research by Japanese academics outside of Japan. However, an aspect related to this issue, is the approach to IS education in Japan. Hence, this section provides a brief insight into educational issues as they relate to the key focus of this paper.

Japanese academics know the international standardized curricula for undergraduate IS education, IS'97 (ACM, AIS and AITP, 1997) and IS2002 (Gorgone et.al., 2002). IS'97 was translated (Ura et al., 1998) and introduced to Japan (Ura et al., 1999; Kaminuma, 1998). IS2002 was also introduced into Japan (Sasaki, 2004). However, despite their efforts it has not been accepted widely into Japanese IS departments, faculties or universities. One reason for this may be that the number of schools that have dedicated IS departments within them remains small. As one interviewee said "Officially, there are only two departments of Information Systems in universities in Japan." The word MIS remains more popular than IS in Japan and there are many more departments of MIS in the universities. IS still has not been recognized as an independent discipline, and its education is usually organized as a subdepartment (course in Japanese) in a department. Otherwise, IS education is conducted as a part of IT (CS) education in a school as a course (class in Japanese).

As IT is universal and ubiquitous in our life and society today, every school does some kind of IT education regardless of the department. Personal productivity with IS Technology (IS 2002.P0) and fundamentals of IS (IS 2002.1) are usually taught. The necessity of IS (2002.P0) is ubiquitous and this is and ought to be taught but IS education remains limited to the above courses in many schools. As one interviewee said "The biggest drawback in our IS education is the narrowness of the area covered and limitation to P0. No more education in IS2002.P0 has been done in many IS schools."

This leads to the identification of another weakness in the Japanese approach to IS education, i.e. paucity of IS faculty members. The number of IS instructors is usually limited to a few in any IS school. As one interviewee of an IS department said "Officially we have 14 instructors in our department, but among them, only three are recognized as IS researchers. Others are not IS but CS or management people and don't write IS papers or obtain memberships in IS academic societies." Another interviewee said "Generally, about a half of IS department consists of CS or CE (computer engineering) people. As a result, education is more CS or CE oriented than IS. Education is limited to IS 2002.P0, programming, and algorithms". Another interviewee said "Although the name of my department is MIS, it is ruled by scientists such as mathematicians and the actual number of IS academics is actually only two. It is considered that these situations came from the history of Japanese universities, that is, the field of application has been disdained and that of fundamentals favored." This situation is also reflected in the great diversity of disciplines represented by members of IS-related academic societies as discussed above. Part of the reason for this situation in Japanese universities is that the difference between IS and other related 
disciplines is not understood by administrators in universities. So IS departments end up employing staff from related disciplines. Also IS as a young discipline inevitably faces the challenge of needing to fill positions with staff who are originally trained in other older disciplines.
The number of core IS staff in most schools remains relatively small. Table 9 lists some results generated from the interviews in terms of education/research workforce in Japanese schools. They appear to be typical of most Japanese IS or IS related departments.

\begin{tabular}{|c|c|c|c|}
\hline \multicolumn{3}{|c|}{ Table 9. IS education in Department being interviewed } \\
\hline & Interviewees & Establishment & \# of IS instructors \\
\hline 1 & A & national & 3 \\
\hline 2 & B & private & 3 \\
3 & C & private & 2 \\
\hline 4 & D & private & 3 \\
\hline 5 & E & prefectural & 4 \\
\hline 6 & F & private & 7 \\
\hline 7 & G & private & 6 \\
\hline 8 & H & private & 1 \\
\hline 9 & I & national & 3 \\
\hline
\end{tabular}

JASMIN organized a task force to design new educational program for undergraduate IS students. Although IS2002 was published as the world standard, and introduced into Japan as noted above, the core members of JASMIN consider it unsuitable to the Japanese IS educational environment. Japanese IS instructors want something different from IS2002. This provides evidence that Japanese IS researchers appear happy to adopt an approach that runs counter to the international standard.

This analysis also investigated the idea that
IS schools and departments in Japanese universities contain fewer dedicated IS staff than those of comparable international IS schools. This analysis calculated the average and standard deviations for Japanese data and AIS data and examined the means of the data (Table 10). AlS data in Table 10 come from section "Research Data and Results", and Japan data from table 9 respectively. It suggests that the average number of IS faculty members in Japanese Universities is smaller than IS schools and universities in USA.

\begin{tabular}{|l|c|c|}
\hline \multicolumn{2}{|c|}{ Table 10 Basic statistics of number of IS faculty in a school } \\
\hline Average & AlS & Japan \\
\hline s.d. & 5.141 & 3.625 \\
\hline Samples & 3.744 & 1.996 \\
\hline
\end{tabular}




\section{Conclusions}

The characteristics of, and factors influencing, Japanese IS research and its under-representation in the international IS community has not been well understood until now. This paper has provided an overview of some key issues in this regard and has indicated key dimensions of the challenges faced. The paper has also provided an empirical comparative analysis of the different research affiliations and foci amongst IS researchers in Japan and the USA. The paper has highlighted that membership of Japanese IS societies is much more diverse than membership amongst the AIS and that there is a stronger business focus in the AIS than amongst the Japanese IS societies. It is also evident that Japanese IS schools are primarily staffed by non-IS staff than is the case internationally.

IS has clearly developed quite differently in Japan from the situation in most other countries, especially the USA. Because of this historical legacy and the strong interdisciplinary nature of IS in Japan, the IS discipline has been defined more widely and has adopted more knowledge from other disciplines than is the situation in most other countries. Although perhaps given the evident differences between USA and European IS, these kind of regional/local differences are not unique to Japan. Nakajima (2003) has noted 'Generally, IS research in the USA tends to be more business and practical oriented'. He continued 'Oppositely, European IS research tends to handle more general subjects about human and society with sociological approach and cultural scientific point of view.'

More broadly, the relatively obscure status of IS in Japan may on the one hand be disadvantageous, but on the other may open up the potential for new and innovative cross-disciplinary developments in the future. Indeed that IS in Japan has not engaged in debates on 'fragmented adhocracy' and 'field legitimacy' may mean that Japanese IS researchers have been able to concentrate research resource on new and interesting domains. However, the development of more standardized global approaches to IS education does mean that Japanese academics will need to become more connected and integrated into the international community over-time.

This paper may be seen as an addition to the IS-in-PA research led by Gable and his colleagues. Gable et. al. (2007b) anticipated an extension of IS-in-PA framework to Japan and to the application of faculty directory archival analysis. This paper has attempted to do address this suggestion.

Before concluding, it is useful to acknowledge some limitations in this paper. Firstly, the number of interviews conducted was relatively small and limited by time and resources. As a result it is somewhat difficult to generalize the findings and thus they should perhaps be viewed as preliminary until further research can be completed. Secondly, the faculty directory analysis, i.e. grouping by name of schools for the empirical study, needs further elaboration. These limitations acknowledged, it is anticipated that this paper has made a contribution to generating research insights in relation IS academic societies and the characteristics and factors influencing Japanese IS research and its under-representation in the international IS community.

\footnotetext{
${ }^{1}$ http://www.ipsj.or.jp/english/index.html

${ }^{2}$ http://www.maebashi-it.ac.jp/ sig/is/index_e.html

${ }^{3} \mathrm{http}: / /$ www.tku.ac.jp/ osamsato/JSIM/

${ }^{4} \mathrm{http}: / /$ home.aisnet.org/joomla/icis/index.asp

${ }^{5} \mathrm{http}: / /$ www.jasmin.jp/english/summary/about/index.html

${ }^{6} \mathrm{http}: / /$ www.ifors.org/About/history.shtml

${ }^{7} \mathrm{http}: / / \mathrm{www} \cdot \mathrm{tku}$. ac.jp/ apcim/index.html

${ }^{8}$ http://issj.nuis.jp/issi/object.html
}

\section{Acknowledgements}

Authors appreciate constructive comments from the blind reviewer. First author appreciates the research fund (A07-15) provided from Tokyo Keizai University. 


\section{References}

ACM, AIS and AITP (1997) "IS'97 Model Curriculum and Guidelines for Undergraduate Degree Programs in Information Systems", The DATA BASE for Advances in Information Systems 28 (1), pp. 1-94.

Avison, D. and S. Elliot (2006) "Scoping the Discipline of Information Systems" in King, J.L. and Lyytinen, K., (Eds.) Information Systems: The State of the Field, John Wiley \& Sons Ltd., pp. 3-18.

Couger, J.D., G.B. Davis, D.L. Feinstein, J.T. Gorgone, and H.E. Falkenberg (1998) "A Framework of Information System Concepts", The FRISCO Report by IFIP, WG 8.1 Task Group FRISCO.

Culnan, M.J. and E.B. Swanson (1986) "Research in Management Information Systems, 1980-1984: Points of Work and References", MIS Quarterly 10 (3), pp. 288-302.

Davis, G.B., A.P. Massey and N. BjornAndersen (2005) "Securing the Future of Information Systems as an Academic Discipline", Proceedings of the Twenty-Sixth International Conference on Information Systems, pp. 979-990.

Gable, G.G., J.N. Lee, K.Y. Kwahk, and P. Green (2007) "Administrative Placement of the Information Systems Academic Discipline: A Comparative SWOT Analysis", Communication of

the Association for Information Systems 21, pp. 137-165.

Gable, G.G. and R.W. Smyth (2007) "The State of the IS Academic Discipline in Pacific Asia 2006: Methodological Learnings", Communications of the Association for Information Systems 21, pp. 166-194.

Gorgone, J.T., G.B. Davis, H.T. Valacich, D. Feinstein, H.Jr. Longenecker (2002)
Model Curriculum and Guidelines for Undergraduate Degree Programs in Information Systems, ACM/AIS/AITP, Retrieved September 9, 2007 from http://192.245.222.212:8009/IS2002Do c/ Main_Frame.htm.

Grover, V., et. al. (2006) "A Citation Analysis of the EVolution and State of Information Systems within a Constellation of Reference Disciplines", Journal of the Association for Information Systems, May 7 (5), pp. 270-325.

Hanaoka, S. (1998) "The Eighth International Conference on Comparative Management (Kaohsiung, Taiwan", Japanese) Office Automation 19 (1), pp. 106-109.

Hirschheim, R. (2003) "Crisis in the IS Field? A Critical Reflection on the State of the Discipline", Journal of the Association for Information Systems 4 (5), pp. 237293.

Hirschheim, R. (2006) "Special Research Perspectives Issue on the IS Core/ldentity Debate", Journal of the Association for Information Systems, October 7 (11), pp. 700-702.

Houjyo, R. (2006) "Remark on Establishment of ISSJ", (Japanese) Journal of Institute of Information Systems Japan 1 (1), pp. i-ii.

Kaminuma, Y. (1998) "IS'97 Model Courses and Learning Units : some implications for teaching text design", (Japanese) Report of SIG Computer and Education, Information Processing Society of Japan.

Longenecker, Jr. (1997) "IS'.97: Model Curriculum and Guidelines for Undergraduate Degree Programs in Information Systems", Data Base 26 (1), pp. I-94.

Lyytinen, K. and J.L. King (2006) "The Theoretical Core and Academic Legitimacy: A Response to Professor Weber", Journal of the Association for 
Information Systems, October 7 (11), pp. 714-721.

Matsui, Y., O. Sato and H. Kitanaka (2007) "IS in Japan" Proceedings on the 2007 DSI annual meeting.

MEXT (Ministry of Education, Culture, Sports, Science and TechNology Japan) "Basic Report of Schools in Japan 2008"

http://www.mext.go.jp/b menu/toukei/0 01/06121219/004.htm, $13^{\text {th }}$ August 2008.

MISRC/McGraw-Hill (1995) Directory of Management Information Systems Faculty, McGraw-Hill.

Nakajima, M. (2003) "Research of IS" (Japanese), http://issj.nuis.jp/concept/01/index.html, $30^{\text {th }}$ May.

Nakajima, M. (2005) "What should be IS discipline?: Beyond Informatics", (Japanese) Proceedings of Information Systems Society Japan, $26^{\text {th }}$ November.

Obata, K. (2006) "A discussion about core of IS research", (Japanese) Journal of Institute of Information Systems Japan 1 (1), pp. 18-23.

Sasaki, H. (2004) "IS2002 Model Curriculum : Is It Applicable or Acceptable in Japan? " (Japanese) Office Automation 24 (4), pp. 34-39.

Sato, O. (1998) "IRM Education Programs for Business Schools: Introducing IRMA Curriculum Model", (Japanese) Office Automation 19 (1), pp. 110-113.

Tohyama, A. (2007) "New Approach to Studying 'Information and Management' and Information TechNology", (Japanese) Joumal of Society for Information and Management 28 (1), pp. 4-13.

Truex, D., J. Holmstrom and M. Keil (2006) "Theorizing in Information Systems
Research: A Reflexive Analysis of the Adaptation of Theory in Information Systems Research", Journal of the Association for Information Systems, December 7 (12), pp. 797-821.

Ura, S. et al (1992) "A Grounded Research to Establish IS Education System", (Japanese), Report to Grant-in-Aid for Scientific Research, The Japan Society for the Promotion of Science, http://www.jsps.go.jp/english/egrants/grants.html.

Ura, S., et al. (1998) IS'97 (Japanese), December, http://www.maebashiit.ac.jp/ sig/is/is97j.pdf .

Ura, S., K. HosoNo, Y. Kaminuma and H. Miyagawa (1999) "IS Research and Educational Trend in UK and US", (Japanese), IPSJ Magazine, July 40 (7), pp. 1-5.

Vessey, I., V. Ramesh and R. Glass (2002) "Research in Information Systems: An Empirical Study of Diversity in the Discipline and Its Journals", Journal of Management Information Systems 19 (2), pp. 129-174.

Wade, M., M. Biehl and H. Kim (2006) "Information Systems is Not a Reference Discipline (And What We Can Do About It) ", Journal of the Association of Information Systems 7 (5), pp. 247-269.

Watson, R., J. Kokuryo, K. Matsudaira, S. Mori, R. Manabe, H. Takagi, O. Sato, and T. Uchiki (1993) "Information Systems in Japan: Education, Research, and Practice", Proceedings of the International Conference on Information Systems 1993.

Weber, R. (2006) "Reach and Grasp in the Debate over the IS Core: An Empty Hand? ", Journal of the Association for Information Systems 7 (11), pp. 703 713. 


\section{About the Authors}

Osam Sato is a full professor of Faculty of Business Administration, Tokyo Keizai University. He received his $\mathrm{BC}$ and MBA degrees from Hitotsubashi University in Tokyo, Japan in 1979 and 1981, respectively. He had studied in Ph.D. course in the university until 1984. After having spent one year as a research fellow at Hitotsubashi University, he joined Faculty of Business Administration, Tokyo Keizai University as a lecturer in 1985. His research interests are in IS, production information systems, information security management and elearning. He had visited to the Carlson School of Management, University of Minnesota, USA, as a visiting researcher from 1990 to 1992. His research has been published in a number of scholarly journals, including Journal of Transnational Management Development, ACM SIGSAC Review, and Information \& Management. He is currently Editor-in-Chief of Journal of the Japan Society for Management Information, and editor of International Journal of Business Information Systems, and Journal of Information Systems Society of Japan.

Takeshi Kosaka is a Professor of Information Systems at Tokyo University of Science. He received MBA from Keio University and Ph.D. in engineering from Sophia University. His interests include the development of SA\&D methodologies in a socio-technical perspective and the interpretive study of ISD. He extended his master and Ph.D. theses into his books on SIS and EIS, respectively. During working in industry he wrote a book on DSS, for which he received Management Science Literature Award from NOMA (Nippon OmniManagement Association). After returning to academia, he has presented papers at international conferences including ICIS, PACIS and MCIS. His articles have appeared in Journal of the Japan society for Management information, Information \& Management, International Journal of Technology Management, and others. $\mathrm{He}$ is currently on the editorial boards of Information Systems Journal (WileyBlackwell), Journal of the Japan Society for Management Information, and Journal of Information Systems Society of Japan.

Paul Turner is an Associate Professor in the School of Computing \& Information Systems at the University of Tasmania. He graduated from the University of London in 1992, completed a Masters degree in Information Systems and Technology in 1994 and was awarded his doctoral degree in 1999. Prior to moving to Australia, Paul was a visiting research fellow at the Universitaires NotreDame de la Paix in Belgium where he worked on a variety of European Commission contracts in the technology domain. His current research interests are in basic, applied and strategic systems approaches to e-health, forensic computing and e-business. Since 2001, Paul has published more than 100 peer-reviewed papers in academic journals, books and conferences and has been directly involved in raising research grants, consultancies and scholarships to a value of more than $\$ 5$ million. Paul is currently Director, eHealth Services Research Group at the University of Tasmania. 